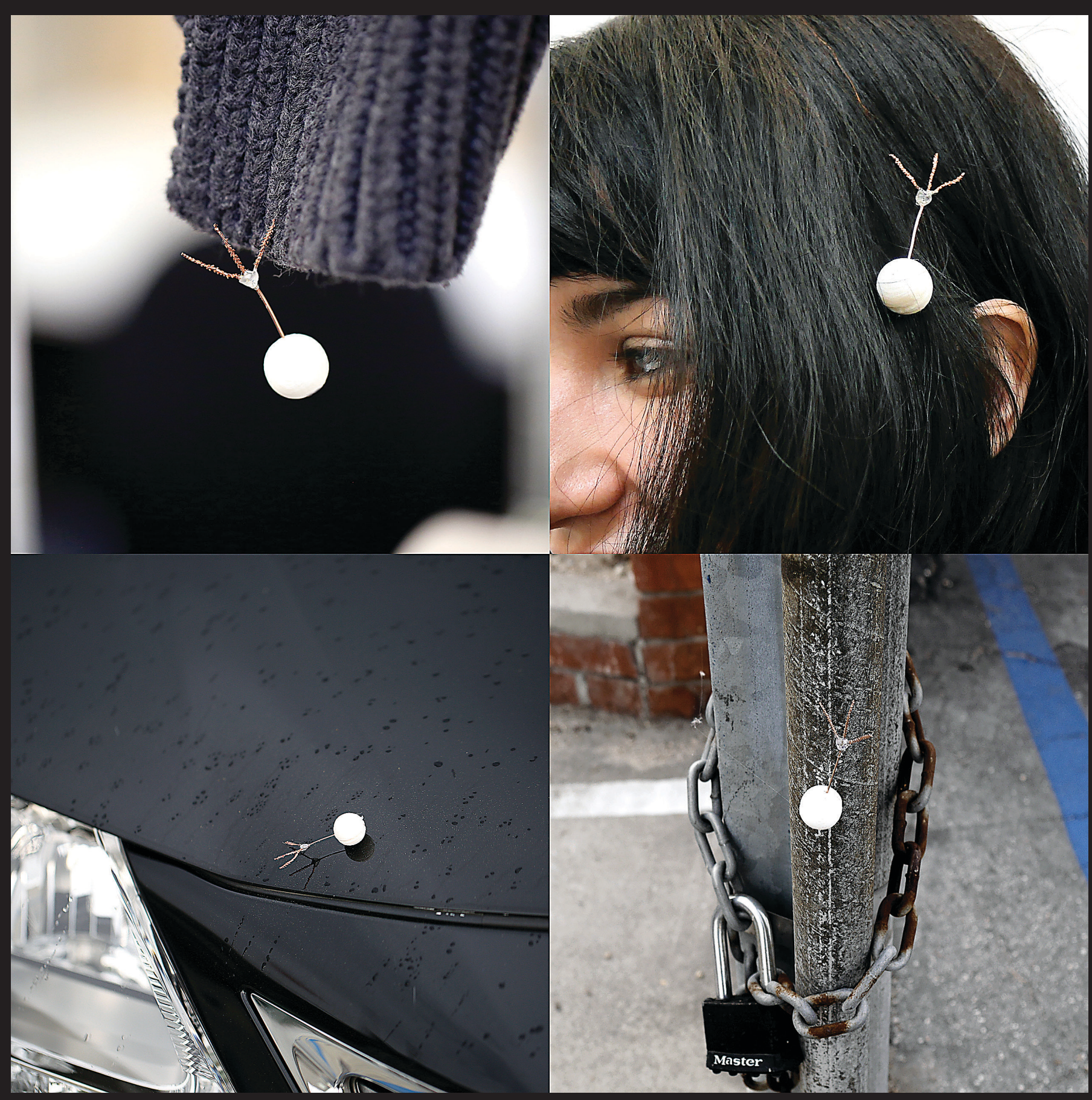

\title{
Plant-Like Robots
}

(1) Contributor: Ji Won Jun

$\rightarrow$ Curator/Editor: Eli Blevis

$\rightarrow$ Genre: Research through design, robots, plant intelligence, seed dispersal

Tiny robots dispersed through the environment like seeds reveal a non-anthropocentric approach to human-robot interaction. 